\title{
A Study on Motivation and its Relationship with Employee Loyalty and Commitment: A Case study of Nama Group- Sultanate of Oman
}

\author{
Ms. Karima Al Balushi, Dr.Syed Aulia* \\ Oman
}

*Corresponding Author: Dr.Syed Aulia, Oman

\begin{abstract}
The intention of this research is to figure out the motivation level and its relationship with employee loyalty and commitment at Nama Group of Companies in Sultanate of Oman. Questionnaire were distributed to the employees at Nama Group. The structured questionnaire is used to get the necessary primary data from the employees, sample size was 70 and middle level employees were sample unit. The total responses received from the questionnaire were 63 employees. The questionnaire is also send as e-link on mobile phones to be more convenient for the employees to fill the questions and also convectional method of collection was implemented. The research finding indicated that the employees at Nama Group are enjoying quality work life, there are having good relationship with each other, they believe that motivation has positive impact on loyalty and commitment of employees. The environment at the organization helps them to work in peaceful manner.
\end{abstract}

Keywords: Motivation, Organizational Climate, Employee Loyalty and Commitment

\section{INTRODUCTION}

In light of increasing pressure at work place, every organization is concerned about their employees. Motivation is important because the employees will perform work to achieve maximum productivity. There are different ways to motivate the employees at work place, appreciate the employees for their good work, make sure that they have the important tools they need to perform their jobs at appropriate manner, stay in touch with employees, answer their calls and questions regarding the job, share some information with employees about how organization is performing its business or responsibilities, keeping the open-door policy, explain to the team that they value their suggestions and proposals. Individuals need organization and organization needs individuals. Each party having expectations from each other, workers are working to achieve the objectives of the organization and they expect financial and non-financial benefit in return.

There are three categories of employees: committed employee who is enthusiastic about his work, non-committed employee: The employee is completely separated from the company in which he works, and this employee works hard and contributes to the success of the company, but the proportion of the rush is less than that enjoyed by the committed employee. It also has the ability to miss or leave the company. There is relationship between employee commitment rate and financial and practical performance. The commitment of employees towards the company leads to higher productivity, better customer service and higher satisfaction rate, less staff absenteeism, higher retention rates, higher job satisfaction rates and good incentive rates. Stimulating employees and motivated them is a challenge. It is easier than it was in the past.

\subsection{Problem Statement}

The issue of non-motivated employees is a major problem for many organization which cost employers billions of dollars each year. The problem is so widespread that some expert sees that70 percent of workers today are less aggressive than they used to be. Dealing with non-motivated employee is one of the most difficult challenges for employers. It is not easy to identify problems that lead to decline in employee's performance, and solving the problem takes a lot of time and effort. Decline in performance may prevent the organization from achieving its goals and objectives, may lead in the productivity and profitability of organization. 


\subsection{Theoretical Concepts and Frame Work}

Motivation is process that pushes the individuals to certain behaviour or specific efforts in order to achieve a goal. Or it is to stimulate the behaviour of the individual to satisfy certain needs, namely to develop the desire to make a higher level of efforts to achieve the objectives of the organization. There are various ways to encourage the employees to be motivated like taking care on small details such as setting the temperature in place so that the atmosphere is not too hot or too cold. Employees will not be excited to work if they feel that there are freezing or sweating they will absolutely lose their focus.

The issue of loyalty attracts the attention of many institution's, reason for this concern is to try to answer the question: why some employee commits in achieving the goals of the organization and work to merge and link themselves with organization and perform their best, while others do not do so. When we talk about Loyalty it is a Positive feeling generated by the employee towards his administrative organization, commitment to its values, dedication to its goals, a constant sense of belonging and pride in belonging to it. Job security is one of the most important element for success in any organization. The idea of job security raises the level of reassurance of the employee on his future career and ending all forms of concern for the future.

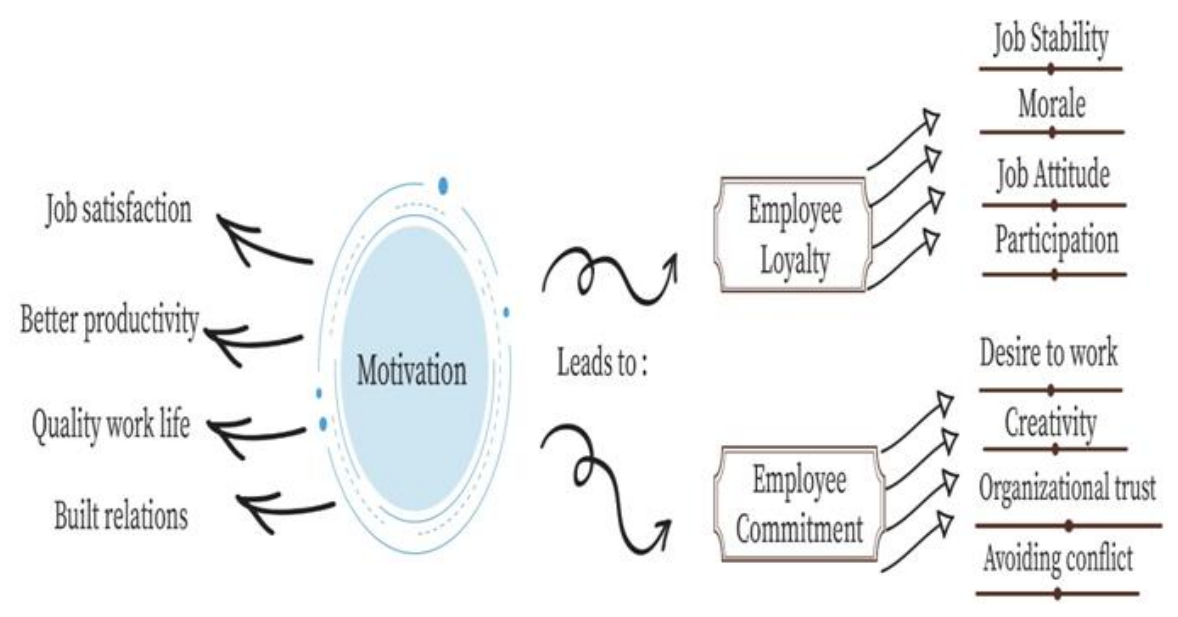

\section{RESEARCH FRAMEWORK}

Motivation will lead to job satisfaction, job satisfaction is feeling of happiness, these feeling give the job an important value of the desire of the individual to work and what surrounds him since the wishes of individuals are different, so there is a difference in direction towards what values are important to them. The organization are interested in studying the wishes of individual and degree of job satisfaction that their behaviour direct towards achieving organizational goals effectively and their belonging to the organization by harnessing advanced management that is in the interest of the employees and their problems using the latest techniques in order to improve employee satisfaction.

Motivation will lead employees to have a quality work life. The work environment has impact on the performance of the employees. The working environment includes several aspects, which consist of physical environment, psychological and social. The physical environment has an important impact on the productivity of employees. Physical environment of work include lighting, heat and noise in the office area. The working environment is not only composed of physical components, but also includes psychological and social aspects. There is a fundamental relationship between material and moral incentives, job satisfaction, social relation and quality of work life.

Loyalty will lead to increase in morale level. Morale is the work spirit, it is intangible, and it can be expressed in many ways. Productivity: If the production level is higher than what was before and the organization is achieving higher profit, this means that the employees have high level of moral. Complaints and grievance: Large number of complaints in the organization is not good, but as a conscious management it is they duty to expedite its research to uncover its truth and address the consequences.

Commitment will lead the individuals to have desire to work more, There are those who have challenges and thinking about solutions, person desire to use his mind and evade the routine life, as an employee he wants to be active, he participates in accomplishing other tasks a part of his assigned duties, he want to work to learn and develop himself. 
Commitment will lead in avoiding the conflict at workplace by having good relations with each other; if any conflict happened between the employees, they should focus on solving the problem and establish better relationships rather than finding faults with each other. If conflict is effectively resolved, it may lead to greater understanding and appreciation of other perspective and stronger relationships at workplace.

\section{LITERATURE REVIEW}

In 2010 the research done by Keizer's was explaining the relationship between intrinsic and extrinsic motivation on employee performance. He said that high level of performance can be achieved when the organization provide specific job characteristics. The study has concluded that the intrinsic factors influence the employee more than extrinsic factors. However, the success of organization is depending on motivated employees. It is stated that employee performance depends on skills, knowledge, experience, personality and abilities. High level job performance is important for the organization as well as for stabilizing the economy. when organization succeed in providing like task identity, skills variety, task significance, autonomy and feedback as mentioned in (Keijzers, 2010) studies concluded that it's possible to encourage employees for good performance. If the employee performed well the internal satisfaction will increase, then the employee will keep in performing well in the future. If the organization provides certain job characteristics then higher performance can be reached.

Effect of Autonomous Motivation is coming within individual and Controlled Motivation, which comes from external sources. The study was conducted by (P.Westers, 2012) focusing on quality of motivation on performance. The study determines whether Autonomous Motivation or Controlled Motivation will have impact in the academic performance of medical student. The study shows that the motivation is important especially for medical student because the medical education is different from general education in many aspects; they are required to carryout clinical work along with studying to be qualified as doctors. The study aimed at enhancing the Autonomous Motivation along with good study strategy and soaring efforts.

The incentive play important role and have direct impact on performance of employee, whether positively or negatively if the incentive is not available or it is available but not equally distributed then it will be reflected on performance of the employee this study is done by(Hamed, 2011)the researcher said that moral stimulation increase the desire of employees and increases their commitment to work schedules which improves the speed of their completion of work. Regarding the impact of financial incentive on improving the performance of employees in ministry, the study showed that its members strongly agree on the effect of financial incentives in improving the performance of employees. They also agree that the financial incentive will increase the following factors: raising the quality of work, speed of work completion, preserving property of ministry and development of human relations.

Motivation plays significant role in level on job commitment toward the job, the employee expose intrinsic and extrinsic element can influence an employee loyalty and commitment. Information was collected from employees in different position and with different educational background. The study used interview method. One of participant said that the incentive whether it is financial or nonfinancial, is of great impact on job, she also said that she is lucky because she is in the right position put in her full efforts at work. Some participant prefer to help others in work place in order to feel happy, some of them prefer to have financial stability, whereas some of them like to have enrichment programs and convenience in work place. The study is done by (Chanel, 2015).

Employee is like investment for the organization they need to attend training programmes, salary, health care and bonuses. Organization trying to develop training programmes and improve the work system should keep in mind the employee's loyalty. It will motivate its employees so the company will not suffer losses. If the employee is working for a long time in the same organization, he is a loyal towards the organization and is hence valuable.

\subsection{The Performance Appraisal Impact on Employee Loyalty and Employee Motivation}

A good employer is the one which helps and give useful employee chance to improve them and listen to employee suggestions and problems. It is suggested recently that the manager should take care and focus on the psychological and physical factor on employees then the employee attitude will improve and hence improves job performance.(Iqbal, 2015) 


\subsection{Concept of Organizational Commitment and Job Satisfaction}

These are two different concepts; it is difficult to separate these two. The employee who has high level of job commitment also have high level of job motivation low level of job conflict and low level of job stress. The employee can have positive feelings about the organization and it goals and objectives but in the same time the employee can have negative feelings regarding his or her post. The purpose of the study was to know relationship between the job commitment and job satisfaction in work place. The employer should look at organizational commitment at the individual level not on group level.(Iden, 2014)

Modern organization aims to achieve success as a monopoly in the field, and human element id defined by the specific element of efficiency such as productivity as strategic resources that effectively reinforces its investment. improve the performance of organization that cannot immediately achieve the rule by using machines such as ICTs, but only if they need to be adequately motivated for the seeking improvement in their performance. It considered as an effective tool for the HR management and increases human performance, with a view to achieving more effective initiatives in order to achieve the objectives of the organization. Study done by (Ahmed, 2012)

If the organization does not use an effective incentive system that covers all categories, it may be exposed to following risks: employee low level of performance, low production and productivity, service and product quality decline, increase in the time spent on completing tasks, employee feel dissatisfaction in their business, less cooperation, absenteeism, take advantage of all opportunities to delay coming to work and seek to leave prematurely, stay away from workplace at rest time. There are factors that define, guide and lead. As long as one does not live in isolation, one does not understand the main determinants of behaviour. Therefore, motivation is one of the components of human behaviour and represents the forces or internal relations that direct the person, between his actions and his behaviour while responding to environmental situation and influences.(mohammed, 2012)

Implementing a special incentive system is one of the most important factors of success in the organization using all possible means to motivate employees to do good work, and incentives are defined as external influence that motivates the individual internal motivation. The motivation is one of the elements of the organized and institutional work. Without it, no organization can achieve its full objectives. The incentive is the way in which the organization expresses the employee's satisfaction with his outstanding performance and is one of the ways that helps the organization achieving its objectives by providing and mastering the financial and employee experience. The incentive cannot achieve their objective in the organization, except with a specific system to manage them in good and optimal manner. With the credibility and justice in applying the incentive system within the organization, to be granted to the owners without excellence and the incentive will be distributed according to the effort, because this leads to achieving role and objectives in an organization (Rashid, 2013)

\subsection{Objectives of the Study}

- To figure out how the motivation, loyalty and commitment plays important role in any organization.

- To know whether there is positive impact or negative impact of motivation on loyalty and commitment of employees

- To find out the reasons which lead to decline in level of motivation, loyalty and commitment

- To investigate whether there is relationship between motivation, loyalty and commitment.

\subsection{Hypotheses}

$\mathrm{H}_{01}$ : There is no significant relationship between motivation and employee loyalty.

$\mathrm{H}_{02}$ : There is no significant relationship between motivation and employee commitment.

\subsection{Scope of the Study}

This paper exanimate the impact of motivation on loyalty and commitment in Nama Group which is a group of joint stock companies registered in Oman. The group consists of ten companies operating in the electricity generation, procurement, transmission, supply and distribution. 


\section{RESEARCH DESIGN}

Descriptive research is used in this study; it describes the data and characteristics of matter under study. It lies in the collection of accurate information. Descriptive method depends on the study of reality or phenomenon, as it cares as a precise description either using qualitative or quantitative method. Qualitative expression describes the phenomenon and explains its characteristics whereas quantities method describes the phenomenon through numbers and tables explaining the size of phenomenon and its association with other phenomena.

\subsection{Sample Size}

Sample size of this study was 70 employees, who are working at Nama Group, Out of 100 employees.

\subsection{Data Collections Method}

Primary data is collected in this study by distributing Questionnaire among the employees at Nama group. Secondary data has been used by internet, published sources and books. The questionnaire method is used it is sent as link in mobile phones to be filled by employees in Nama Group. Structured questionnaire is prepared considering research topic and problem and then identifying the data and information required to be collected.

\subsection{Analysis of Data}

\subsubsection{Tools and Techniques}

Excel SPSS and other related statistical tools.

\subsubsection{Limitation of Study}

- The time was insufficient to go for interview method for collecting primary data.

- Unintentional human error while collecting data or interpreting results.

\section{Finding OF THE STUDY- RESUlt \& DisCUSSION}

\subsection{Respondents Profile}

Age of respondents:

\begin{tabular}{|l|l|l|l|}
\hline \multicolumn{1}{|c|}{ Age Group } & \multicolumn{1}{|c|}{ Frequency } & \multicolumn{1}{c|}{ Valid Percent } & Cumulative Percent \\
\hline $20-30$ & 18 & 28.6 & 28.6 \\
\hline $31-40$ & 27 & 42.9 & 71.4 \\
\hline $41-50$ & 17 & 27.0 & 98.4 \\
\hline More than 50 & 1 & 1.6 & 100.0 \\
\hline Total & 63 & 100.0 & \\
\hline
\end{tabular}

Interpretations: 18 of the respondent $(28.6 \%)$ ) where in the age group of 20-30, 27 of the employees (42.9\%) where in the age group of 31-40, 17 of them (27.0\%) where in the age group 41-50, 1 of the employees $(1.6 \%)$ ) was at age group of more than 50 years.

Gender of respondents:

\begin{tabular}{|l|r|r|r|}
\hline Gender & Frequency & Valid Percent & Cumulative Percent \\
\hline Female & 22 & 34.9 & 34.9 \\
\hline Male & 41 & 65.1 & 100.0 \\
\hline Total & 63 & 100.0 & \\
\hline
\end{tabular}

Interpretation: 22 of the employees $(34.9 \%)$ were females, Whereas, 41 of the employees $(65.1 \%)$ were males.

Experience of respondents:

\begin{tabular}{|l|l|l|l|l|l|}
\hline \multicolumn{2}{|c|}{ Experience } & Frequency & Percent & Valid Percent & Cumulative Percent \\
\hline Valid & $1-5$ & 24 & 38.1 & 38.1 & 38.1 \\
\cline { 2 - 6 } & $6-10$ & 31 & 49.2 & 49.2 & 87.3 \\
\cline { 2 - 6 } & More than 10 & 8 & 12.7 & 12.7 & 100.0 \\
\cline { 2 - 5 } & Total & 63 & 100.0 & 100.0 & \\
\hline
\end{tabular}

Interpretation: 24 of the employees $(38.1 \%)$ had an experience of 1-5 years, 31 of employees $(49.2 \%)$ had experience of 6-10 years, and 8 employees $(12.7 \%)$ had experience more than 10 years. 
A Study on Motivation and its Relationship with Employee Loyalty and Commitment: A Case study of Nama Group-Sultanate of Oman

Nationality of respondents

\begin{tabular}{|c|l|r|r|r|}
\hline \multicolumn{2}{|c|}{ Nationality } & Frequency & Valid Percent & Cumulative Percent \\
\hline \multirow{3}{*}{ Valid } & Omani & 47 & 74.6 & 74.6 \\
\cline { 2 - 5 } & Non Omani & 16 & 25.4 & 100.0 \\
\cline { 2 - 5 } & Total & 63 & 100.0 & \\
\hline
\end{tabular}

Interpretation: 47 employees (74.6\%)) were Omani and 16 of employees (25.4\%)) were non-Omani

Do you believe that the motivated employees can give more quality work or better productivity than the others?

\begin{tabular}{|l|l|l|l|l|l|}
\hline \multicolumn{2}{|c|}{ Parameter } & Frequency & Percent & Valid Percent & Cumulative Percent \\
\hline Valid & Strongly Agree & 18 & 28.6 & 28.6 & 28.6 \\
\cline { 2 - 6 } & Agree & 31 & 49.2 & 49.2 & 77.8 \\
\cline { 2 - 6 } & Neutral & 7 & 11.1 & 11.1 & 88.9 \\
\cline { 2 - 6 } & Disagree & 4 & 6.3 & 6.3 & 95.2 \\
\cline { 2 - 6 } & Strongly Disagree & 3 & 4.8 & 4.8 & 100.0 \\
\cline { 2 - 6 } & Total & 63 & 100.0 & 100.0 & \\
\hline
\end{tabular}

Interpretation: 49 of employees agree $(77.7 \%)$ that motivated employees can give more quality work or better productivity than others.

I am satisfied with following factors (income, health and safety policy)

\begin{tabular}{|c|l|l|l|l|l|}
\hline \multicolumn{2}{|l|}{ Parameter } & Frequency & Percent & Valid Percent & Cumulative Percent \\
\hline Valid & Strongly Agree & 22 & 34.9 & 34.9 & 34.9 \\
\cline { 2 - 5 } & Agree & 26 & 41.3 & 41.3 & 76.2 \\
\cline { 2 - 5 } & Neutral & 7 & 11.1 & 11.1 & 87.3 \\
\cline { 2 - 5 } & Disagree & 4 & 6.3 & 6.3 & 93.7 \\
\cline { 2 - 6 } & Strongly Disagree & 4 & 6.3 & 6.3 & 100.0 \\
\cline { 2 - 6 } & Total & 63 & 100.0 & 100.0 & \\
\hline
\end{tabular}

Interpretation: 48 employees $(41.3 \%)$ are satisfied with income, health, and safety

I have good relationship with my co-worker

\begin{tabular}{|c|l|r|r|r|r|}
\hline \multicolumn{2}{|c|}{ Parameter } & Frequency & Percent & Valid Percent & Cumulative Percent \\
\hline Valid & Strongly Agree & 26 & 41.3 & 41.3 & 41.3 \\
\cline { 2 - 6 } & Agree & 18 & 28.6 & 28.6 & 69.8 \\
\cline { 2 - 6 } & Neutral & 13 & 20.6 & 20.6 & 90.5 \\
\cline { 2 - 6 } & Disagree & 3 & 4.8 & 4.8 & 95.2 \\
\cline { 2 - 6 } & Strongly Disagree & 3 & 4.8 & 4.8 & 100.0 \\
\cline { 2 - 6 } & Total & 63 & 100.0 & 100.0 & \\
\hline
\end{tabular}

Interpretation: 44 employees $(69.8 \%)$ have good relationship with co-worker

Job stability will affect employee loyalty

\begin{tabular}{|l|l|l|l|l|l|}
\hline \multicolumn{2}{|c|}{ Parameter } & Frequency & Percent & Valid Percent & Cumulative Percent \\
\hline Valid & Strongly Agree & 27 & 42.9 & 42.9 & 42.9 \\
\cline { 2 - 6 } & Agree & 23 & 36.5 & 36.5 & 79.4 \\
\cline { 2 - 6 } & Neutral & 6 & 9.5 & 9.5 & 88.9 \\
\cline { 2 - 6 } & Disagree & 2 & 3.2 & 3.2 & 92.1 \\
\cline { 2 - 6 } & Strongly Disagree & 5 & 7.9 & 7.9 & 100.0 \\
\cline { 2 - 6 } & Total & 63 & 100.0 & 100.0 & \\
\hline
\end{tabular}

Interpretation: 50 of employees (79.3\%) agree that job stability affect employee loyalty.

Usually committed employee will not be interested in doing tasks which are not part of his assigned duties.

\begin{tabular}{|l|l|l|l|l|l|}
\hline \multicolumn{2}{|c|}{ Parameter } & Frequency & Percent & Valid Percent & Cumulative Percent \\
\hline Valid & Strongly Agree & 1 & 1.6 & 1.6 & 1.6 \\
\cline { 2 - 6 } & Agree & 2 & 3.2 & 3.2 & 4.8 \\
\cline { 2 - 6 } & Neutral & 5 & 7.9 & 7.9 & 12.7 \\
\cline { 2 - 6 } & Disagree & 29 & 46.0 & 46.0 & 58.7 \\
\cline { 2 - 6 } & Strongly Disagree & 26 & 41.3 & 41.3 & 100.0 \\
\cline { 2 - 6 } & Total & 63 & 100.0 & 100.0 & \\
\hline
\end{tabular}


A Study on Motivation and its Relationship with Employee Loyalty and Commitment: A Case study of Nama Group-Sultanate of Oman

Interpretation: 29 of employees $(46.0 \%)$ disagree that committed employees will not be interested in doing tasks which are not part of his assigned duties.

When an employee is committed toward his job he/she can have more sense of creativity

\begin{tabular}{|c|l|l|l|l|l|}
\hline \multicolumn{2}{|l|}{ Parameter } & Frequency & Percent & Valid Percent & Cumulative Percent \\
\hline Valid & Strongly Agree & 17 & 27.0 & 27.0 & 27.0 \\
\cline { 2 - 6 } & Agree & 35 & 55.6 & 55.6 & 82.5 \\
\cline { 2 - 6 } & Neutral & 4 & 6.3 & 6.3 & 88.9 \\
\cline { 2 - 6 } & Disagree & 2 & 3.2 & 3.2 & 92.1 \\
\cline { 2 - 6 } & Strongly Disagree & 5 & 7.9 & 7.9 & 100.0 \\
\cline { 2 - 6 } & Total & 63 & 100.0 & 100.0 & \\
\hline
\end{tabular}

Interpretation: 52 of employees (82.5\%) agree that employees can create more sense of creativity when they are committed toward their jobs

There is relationship between job satisfaction and the overall organizational performance

\begin{tabular}{|c|l|l|l|l|l|}
\hline \multicolumn{2}{|c|}{ Parameter } & Frequency & Percent & Valid Percent & Cumulative Percent \\
\hline Valid & Strongly Agree & 31 & 49.2 & 49.2 & 49.2 \\
\cline { 2 - 5 } & Agree & 24 & 38.1 & 38.1 & 87.3 \\
\cline { 2 - 5 } & Neutral & 4 & 6.3 & 6.3 & 93.7 \\
\cline { 2 - 5 } & Disagree & 2 & 3.2 & 3.2 & 96.8 \\
\cline { 2 - 6 } & Strongly Disagree & 2 & 3.2 & 3.2 & 100.0 \\
\cline { 2 - 6 } & Total & 63 & 100.0 & 100.0 & \\
\hline
\end{tabular}

Interpretation: 55 of employees (87.3\%) agree that there is relationship between job satisfaction and overall organizational performance

Motivation has positive impact on loyalty and commitment of employees

\begin{tabular}{|c|l|l|l|l|l|}
\hline \multicolumn{2}{|c|}{ Parameter } & Frequency & Percent & Valid Percent & Cumulative Percent \\
\hline \multirow{6}{*}{ Valid } & Strongly Agree & 22 & 34.9 & 34.9 & 34.9 \\
\cline { 2 - 6 } & Agree & 34 & 54.0 & 54.0 & 88.9 \\
\cline { 2 - 6 } & Neutral & 3 & 4.8 & 4.8 & 93.7 \\
\cline { 2 - 6 } & Disagree & 2 & 3.2 & 3.2 & 96.8 \\
\cline { 2 - 6 } & Strongly Disagree & 2 & 3.2 & 3.2 & 100.0 \\
\cline { 2 - 6 } & Total & 63 & 100.0 & 100.0 & \\
\hline
\end{tabular}

Interpretation: 56 of employees $(88.8 \%$ ) believe that motivation has positive impact on loyalty and commitment of employees

Do you agree that motivation, loyalty and commitment are important in any organization

\begin{tabular}{|c|l|l|l|l|l|}
\hline \multicolumn{2}{|c|}{ Parameter } & Frequency & Percent & Valid Percent & Cumulative Percent \\
\hline Valid & Strongly Agree & 23 & 36.5 & 36.5 & 36.5 \\
\cline { 2 - 6 } & Agree & 34 & 54.0 & 54.0 & 90.5 \\
\cline { 2 - 6 } & Neutral & 4 & 6.3 & 6.3 & 96.8 \\
\cline { 2 - 6 } & Disagree & 1 & 1.6 & 1.6 & 98.4 \\
\cline { 2 - 6 } & Strongly Disagree & 1 & 1.6 & 1.6 & 100.0 \\
\cline { 2 - 6 } & Total & 63 & 100.0 & 100.0 & \\
\hline
\end{tabular}

Interpretation: 57 of employee (90.4\%) sees that motivation, loyalty and commitment are important in any organization

Freedom at workplace motivate me to do more work

\begin{tabular}{|c|l|l|l|l|l|}
\hline \multicolumn{2}{|c|}{ Parameter } & Frequency & Percent & Valid Percent & Cumulative Percent \\
\hline \multirow{6}{*}{ Valid } & Strongly Agree & 27 & 42.9 & 42.9 & 42.9 \\
\cline { 2 - 6 } & Agree & 35 & 55.6 & 55.6 & 98.4 \\
\cline { 2 - 6 } & Neutral & 1 & 1.6 & 1.6 & 100.0 \\
\cline { 2 - 6 } & Total & 63 & 100.0 & 100.0 & \\
\hline
\end{tabular}

Interpretation: 62 of employees $(98.4 \%)$ believe that freedom at workplace will motivate them to work more. 
A Study on Motivation and its Relationship with Employee Loyalty and Commitment: A Case study of Nama Group-Sultanate of Oman

Organization climate help to work in peaceful manner

\begin{tabular}{|c|l|l|l|l|l|}
\hline \multicolumn{2}{|c|}{ Parameter } & Frequency & Percent & Valid Percent & Cumulative Percent \\
\hline Valid & Strongly Agree & 27 & 42.9 & 42.9 & 42.9 \\
\cline { 2 - 6 } & Agree & 32 & 50.8 & 50.8 & 93.7 \\
\cline { 2 - 6 } & Neutral & 1 & 1.6 & 1.6 & 95.2 \\
\cline { 2 - 6 } & Disagree & 1 & 1.6 & 1.6 & 96.8 \\
\cline { 2 - 6 } & Strongly & 2 & 3.2 & 3.2 & 100.0 \\
\cline { 2 - 6 } & Disagree & & 100.0 & 100.0 & \\
\cline { 2 - 6 } & Total & 63 & 100 & \\
\hline
\end{tabular}

Interpretation: 59 of employees (93.6\%) agree that organizational climate help them to work in peaceful manner Reliability score for Motivation

\begin{tabular}{|c|c|c|}
\hline Cronbach's Alpha & $\begin{array}{c}\text { Cronbach's Alpha Based on } \\
\text { Standardized Items }\end{array}$ & N of Items \\
\hline .875 & .884 & 20 \\
\hline
\end{tabular}

The Cronbach's alpha coefficient for the twenty questions is $\alpha=.875$, which means that the items have high internal consistency.

\subsection{Testing of Hypotheses}

\section{Hypothesis I}

$\mathrm{H}_{01}$ : There is no significant relationship between motivation and employee loyalty.

Correlation between Motivation and Employee Loyalty in the organization

\begin{tabular}{|l|l|l|l|}
\hline \multicolumn{2}{|c|}{ Motivation } & \multicolumn{1}{|c|}{ Motivation } & Employee Loyalty \\
\hline & Pearson Correlation & 1 & $.589^{* *}$ \\
\cline { 2 - 4 } & Sig. (2-tailed) & & .000 \\
\cline { 2 - 4 } & $\mathrm{N}$ & 63 & 63 \\
\hline \multirow{3}{*}{$\begin{array}{l}\text { Employee } \\
\text { Loyalty }\end{array}$} & Pearson Correlation & $.589^{* *}$ & 1 \\
\cline { 2 - 4 } & Sig. (2-tailed) & .000 & \\
\cline { 2 - 4 } & $\mathrm{N}$ & 63 & 63 \\
\hline
\end{tabular}

**. Correlation is significant at the 0.01 level (2-tailed).

According to the results displayed in the table above, where $r=.589$ and $p=.000$, we can conclude that the null hypothesis $\mathrm{H}_{01}$ gets rejected. It implies that, there is a statistically significant positive relationship between motivation and employee loyalty in organization.

\section{Hypothesis - II}

$\mathrm{H}_{02}$ : There is no significant relationship between motivation and employee commitment.

Correlation between Motivation and Employee Commitment

\begin{tabular}{|l|l|l|l|}
\hline \multicolumn{2}{|c|}{} & Motivation & \multicolumn{1}{c|}{ Employee commitment } \\
\hline \multirow{3}{*}{ Motivation } & Pearson Correlation & 1 & $.577^{\text {*** }}$ \\
\cline { 2 - 4 } & Sig. (2-tailed) & & .000 \\
\cline { 2 - 4 } & $\mathrm{N}$ & 63 & 63 \\
\hline \multirow{3}{*}{ Employee commitment } & Pearson Correlation & $.577^{* *}$ & 1 \\
\cline { 2 - 4 } & Sig. (2-tailed) & .000 & \\
\cline { 2 - 4 } & $\mathrm{N}$ & 63 & 63 \\
\hline
\end{tabular}

**. Correlation is significant at the 0.01 level (2-tailed).

According to the results displayed in the table above, where $r=.577$ and $p=.000$, we can conclude that the null hypothesis $\mathrm{H}_{02}$ gets rejected. It implies that, there is a statistically significant positive relationship between motivation and employee commitment in organization.

\subsection{Discussion on Findings of the Study}

The questionnaire result indicates that the employees agree that motivation is linked with loyalty and commitment toward the job. They believe that if the employee is committed toward his or her job they will able to perform the task which is not a part of his or her assigned duties. The employees believe 
that if the fair policy is established at work place it will encourage the employee to be more motivated and loyal to the job.

The company follows the Omanization policy as the percentage of expatriates is lower than the Omani worker. The workers are satisfied with their income, health insurance and safety policy, they believe that moral can be expressed in terms of higher production and higher profit, that also believe that the when the conflict is effectively resolved it will lead to employee commitment toward work.

The employees see that the existing of freedom at work place enable them to be more creative while performing their duties. The employee has good relationship to each other. High level of loyalty of the individual toward the job in which he works in manner that leads to positive interaction between him the work environment, this interaction does not result in fusion of all individual qualities, trends and values except within certain limit, the interaction on the refinement and the disappearance of some undesirable values, characteristic and behavioural patterns that have a significant impact on the work of the individual within the work environment

high level of job satisfaction leads to high level of ambition among employees, and a close relationship between job satisfaction and production at work the higher the degree of satisfaction the greater the production. Employee motivation is one of important the indicator that reveal the health and wellness of the company, noting that the employee is willing to continue to achieve company's goals and objectives.

18 of the respondent (28.6\%) where in the age group of 20-30, 27 of the employees (42.9\%) where in the age group of $31-40,17$ of them (27.0\%) where in the age group 41-50, 1 of the employees (1.6 $\%$ ) was at age group of more than 50 years. 22 of the employees (34.9\%) were females, 41 of the employees $(65.1 \%)$ were males.24 of the employees $(38.1 \%)$ had an experience of 1-5 years, 31 of employees $(49.2 \%)$ had experience of 6-10 years, and 8 employees $(12.7 \%)$ had experience more than 10 years.47 employees (74.6\%)) were Omani and 16 of employees $(25.4 \%)$ ) were non-Omani. 49 of employees agree $(77.7 \%)$ that motivated employees can give more quality work or better productivity than others. 48 employees $(41.3 \%)$ are satisfied with income, health, and safety. 44 employees $(69.8 \%)$ have good relationship with co-worker. 59 of employees $(93.6 \%)$ agree that organizational climate help them to work in peaceful manner. 50 of employees (79.3\%) agree that job stability affect employee loyalty. 29 of employees (46.0\%) disagree that committed employees will not be interested in doing tasks which are not part of his assigned duties.

The employees feel confidence in work and loyalty and belonging which lead in increase the efficiency of performance and production. The employees at Name Group have good relationship with each other, they have strong links, these links are increasing significantly in the times of stress and crisis, one of the most important factors to build positive relationships with colleagues is empathy the ability to feel what another employee feels by understanding their psyche and living creating a kind of harmony and familiarity with in the organization.

\section{CONCLUSION}

This research focuses on motivation and it affects the loyalty and commitment of employee. The objectives of the research were to know how the motivation, loyalty and commitment plays important role in the organization, it is figure out if the employee is motivated they will perform more quality work and better productivity than others, also if the employee is motivated he will perfume some task which is don't part of his assigned duty, they have more sense of creativity.

Through the questionnaire we find out that motivation has positive impact on loyalty and comment of employees at Nama Group. The reason for declining the motivation level is not having fair policy, not having good relationship with co-worker, not having healthy work environment, if incentive is not provided to the employees.

There is direct relationship between motivation, loyalty and commitment. the result show that people prefer financial incentive more than non-financial incentive, the employee tend to improve the level of performance if they having good financial incentive they will be more committed toward the job, also the result indicated that non-financial incentive do not affect the motivation, loyalty and commitment.

The result of statistical analysis concluded that financial incentive is more effective than non-financial incentive, the employee are happy about their salary, safety policy and health insurance, it means they 
are enjoying quality of work life. Job stability will affect employee loyalty, the impact of security and jobs stability which is provided by company to the employees it act as incentive for individual because the stable work provides a decent living income, the employees agreed that the morale can be expressed in terms of higher production and higher profit. The result shows if the employee is committed toward the job he or she will ready to perform the task which is not part of his or her assigned duties.

52 of employees $(82.5 \%)$ agree that employees can create more sense of creativity when they are committed toward their jobs. 55 of employees $(87.3 \%)$ agree that there is relationship between job satisfaction and overall organizational performance. 56 of employees (88.8\%) believe that motivation has positive impact on loyalty and commitment of employees. 57 of employee $(90.4 \%)$ sees that motivation, loyalty and commitment are important in any organization.62 of employees $(98.4 \%)$ believe that freedom at workplace will motivate them to work more.

Conflict is effectively resolved at work place it will lead to employee commitment toward work, job satisfaction is important for overall organizational performance, if the employees are satisfied they will perform work in appropriate manner.

There is mutual respect between colleagues at work, this contributes to an atmosphere of familiarity between them, overall they have good relationship with each other, the employees feel comfortable to practice their profession or work at the company.

\subsection{Suggestions}

- There is a need to provide work system which is acceptable by the employees

- There is need to focus on team work sense the employees at Nama Group have good relationship with each other.

- Periodic check of motivation level of employees it required to ensure everything are going as it planned

- More flexibility in hours of working may paly important role in motivating employees

\subsection{Direction Future Research}

- The study can be done to compare the motivation level between two or more companies, not just focusing in one company.

- The interview method can be used to get deep information.

- The study can be conducted in international or large companies which have more number of employees

\section{REFERENCES}

[1] Abd Hair Awang, R. I. (2010). Retrieved from http://www.tandfonline.com/doi/pdf/10.1080/1331677X .2010. 11517434? needAccess=tru

[2] Ahmed. (2012). Retrieved from http://www.univ-tebessa.dz/fichiers/master/master_2147.pdf

[3] Awang, A. H. (2015). Retrieved from Economic Research: http://www.tandfonline.com/doi/pdf/10.1080/ 1331677X.2010.11517434?needAccess=true \&

[4] Aziz, A. (2016). Retrieved from ProQuest: https://search-proquest-com.ez.library.latrobe.edu.au/docview/ 1876706769?rfr_id=info\%3Axri\%2Fsid\%3Aprim

[5] hDps://spea.indiana.edu/doc/undergraduate/ugrd_thesis2012_mgmt_burton.pdf

[6] Chanel, M. (2015). Retrieved from https://www.trinitydc.edu/bgs/files/2015/01/Smith-Marquita-FinalVersion-4_25_15.pdf

[7] D, B. (2010). Retrieved from http://www.sciencedirect.com.ez.library.latrobe.edu.au/science/article /pii/ S0048733310000594

[8] Dixit, D. V. (2012). Retrieved from http://ejbss.com/Data/Sites/1/septemberissue/ejbss-12-1147-astudy aboutemployeecommitment.pdf

[9] Elnaga1, A. (2013). Retrieved from IISTE: http://pakacademicsearch.com/pdf-files/ech/517/137-147\%20 Vol\%205,\%20No\%204\%20(2013).pdf 
A Study on Motivation and its Relationship with Employee Loyalty and Commitment: A Case study of Nama Group-Sultanate of Oman

[10] Francisco. (2017, Jan ). Retrieved from ProQuest: https://search-proquest-com.ez.library.latrobe.edu.au /citedreferences/MSTAR_1858297365/F15F211BD16E4127PQ/1?accountid=12001

[11] Ghaffar, M. (2015). Retrieved from http://studies.aljazeera.net/ar/mediastudies/2015/05/201551 295922815495.html

[12] Giangreco. (2009). Retrieved from http://www.tandfonline.com.ez.library.latrobe.edu.au/doi/pdf/10.1080/ 09585190802528417 ?needAccess $=$ true

[13] Hamed, a. (2011). Retrieved from http://www.abahe.co.uk/Research-Papers/Impact-of-material-andmoral-incentives-to-improve-the-performance-of-employees.pdf

[14] Ibrahim. (2016). Retrieved from http://www.emeraldinsight.com/doi/pdfplus/10.1108/EJTD-08-2016-0066

[15] Ibrahim, R. (2016). Retrieved from emerald insight: http://www.emeraldinsight.com/doi/pdfplus/10.1108 /EJTD-08-2016-0066

[16] Iden, L. M. (2014). Retrieved from https://brage.bibsys.no/xmlui/bitstream/handle/11250/221551/ Masterthesis.pdf

[17] Iqbal, A. (2015). Retrieved from file:///C:/Users/karim/Desktop/study2.pdf

[18] Ismail, W. (2011). Retrieved from http://www.shatharat.net/vb/showthread.php?t=8866

[19] Jones. (2007). Retrieved from ttp://www.emeraldinsight.com.ez.library.latrobe.edu.au/doi/full/10.1108/ 01425450810835419

[20] Katherine. (2017). Retrieved from https://www.td.org/Publications/Blogs/Global-HRD-Blog/2017/05/5Trends-Changing-Training-in-the-Middle-East

[21] Keijzers, B. ( 2010 ). Retrieved from http://arno.uvt.nl/show.cgi?fid=121057

[22] Keijzers, B. (2010). Retrieved from http://arno.uvt.nl/show.cgi?fid=121057

[23] Khalaf, D. B. (n.d.). recent trends in training.

[24] mohammed. (2012). Retrieved from http://unpan1.un.org/intradoc/groups/public/documents/arado/unpan 009675.pdf

[25] mohammed, w. (2008). Retrieved from http://www.alazhar.edu.ps/journal123/attachedFile.asp?seqq1=1484

[26] Musser, K. t. (2005). Retrieved from http://ps.psychiatryonline.org.ez.library.latrobe.edu.au/doi/full/ 10.1176/appi.ps.56.10.125P, S. J. (2015). Retrieved from Science Direct: http://www.sciencedirect.com .ez.library.latrobe.edu.au/science/article/pii/S1048984315000466

[27] P.Westers. (2012). Retrieved from hDps://www.ncbi.nlm.nih.gov/pmc/ar\#cles/PMC3569579/

[28] Pavelich. (2011).

[29] Proudfoot. (2009). Retrieved from http://www.sciencedirect.com.ez.library.latrobe.edu.au/science/ article/pii/S0191886908003462

[30] Rashid, M. (2013). Retrieved from http://www.enssea.net/enssea/majalat/2221.pdf

[31] Seyed. (2014). Retrieved from file://C:/Users/karim/Desktop/33.pdf

[32] Tyler, K. (2009). Retrieved from EBSCOhost.

[33] Waseem, D. (2011). Retrieved from http://www.shatharat.net/vb/showthread.php?t=8866

[34] Weal. (2010). Retrieved from http://www.alazhar.edu.ps/journal123/attachedFile.asp?seqq1=1484

[35] Wilikins. (2001). Retrieved from http://opus.bath.ac.uk/21255/1/International_briefing_9__Training_and_development_in_the_United_Arab_Emirates.pdf

[36] Wilkins, S. (2001). Retrieved from http://opus.bath.ac.uk/21255/1/International_briefing_9__Training_and_development_in_the_United_Arab_Emirates.pdf

Citation: Ms. Karima Al Balushi, Dr.Syed Aulia. "A Study on Motivation and its Relationship with Employee Loyalty and Commitment: A Case study of Nama Group-Sultanate of Oman" International Journal of Managerial Studies and Research (IJMSR), vol 7, no. 4, 2019, pp. 112-122. doi: http://dx.doi.org/10.20431/ 2349-0349.0704015.

Copyright: (C) 2019 Authors. This is an open-access article distributed under the terms of the Creative Commons Attribution License, which permits unrestricted use, distribution, and reproduction in any medium, provided the original author and source are credited. 